\title{
A note on the systematic position of the Bathynellacea (Crustacea, Malacostraca) using molecular evidence
}

\author{
Ana Isabel Camacho', Isabel Rey ${ }^{2}$, Beatriz A. Dorda ${ }^{2}$, Annie Machordom ${ }^{3}$, Antonio G. Valdecasas ${ }^{3}$ \\ ${ }^{1}$ Museo Nacional de Ciencias Naturales (CSIC), Dpto. Biodiversidad y Biologia Evolutiva. C/ José Gutiérrez \\ Abascal 2, 28006-Madrid, Spain, mcnac22@mncn.csic.es; ${ }^{2}$ Museo Nacional de Ciencias Naturales (CSIC), \\ Dpto. de Colecciones. C/José Gutiérrez Abascal 2, 28006-Madrid; ${ }^{3}$ Museo Nacional de Ciencias Naturales \\ (CSIC), Dpto. Biodiversidad y Biologia Evolutiva. C/ José Gutiérrez Abascal 2, 28006-Madrid.
}

Keywords: Systematics, Crustacea, Malacostraca, Bathynellacea, 16S rDNA.

\begin{abstract}
Molecular data for the mt 16S rDNA gene fragment of a bathynellacean is here presented for the first time and used to analyze the relationship of the group within the crustacean class Malacostraca (Arthropoda, Bathynellacea). Two contrasting views have classified the bathynelids as being either within the order Syncarida or in a separate super-order Podophallocarida belonging to the infra-class Eonomostraca, a disagreement based mainly on debates over external and internal morphology. The preliminary analyses offered here in question the placement of this Bathynellacea within the Syncarida, and suggest the need for a further study of relationships among the malacostracan groups.
\end{abstract}

\section{Contents}

Abstract

Introduction

Brief natural history of the Bathynellacea $\quad 124$

Material and methods $\quad 124$

Results $\quad 125$

Discussion $\quad 126$

On the phylogenetic relationships of Bathynellacea $\quad 126$

Acknowledgements $\quad 128$

References

128

\section{Introduction}

The relative merit of the systematic position given to a certain group of animals or plants, depends more often than not on how thoroughly the group has been studied rather than the technique used. Contrasting morphological studies with molecular ones has often had the undesirable effect of concealing that neither view, morphological or molecu- lar, is usually homogeneous amongst the specialists. The traditional way of working is to use the latest information or the latest hypothesis published in order to select those views that are going to be compared. However, it must be universal that where there is more than one taxonomist working on a group there will not be a single hypothesis or interpretation of the group's descent. How big or small are these irrelevant discrepancies and does it not invalidate this universal law.

The group known as "Bathynellacea" (Serban, 1972 ) is a good example of the above. First discovered by Vejdovsky (1882), their systematic (position) has been a problem since then. They were considered an "aberrant" member of Malacostraca (Calman, 1909). Although nobody knows what "aberrant" members in evolution are, the term generally implies organisms that do not fit well into our limited reconstructed ground patterns. Other authors have designated them as simplified syncarids (see Schminke, 1981). However, the morphological taxonomist that most deeply studied the internal and external morphology of the Bathynellacea, Eugene Serban, never joined the Bathynellacea with the Syncarida, but proposed a more radical model of relationships (Serban, 1970, 1972): the order Bathynellacea in his scheme would belong to the superorder Podophallocarida Serban, 1970 under the infraclass Eonomostraca Serban, 1972. True Syncarida, on the other hand, would be placed by Serban under a different infraclass, the Anomostraca.

In this paper we present the first nucleotide data for a bathynellacean species and apply these towards an analysis of the relationship of this group with other malacostracan crustaceans. 


\section{Brief natural history of the Bathynellacea}

Bathynellacea are small crustaceans, between 0.5 and $3 \mathrm{~mm}$ in size, with an almost cylindrical body and vermiform shape, without eyes or pigmentation. All known species live in the interstitial environment (stygobionts), either in cave groundwater or phreatic water close to epigean rivers and aquifers. Only 2 species that live free in Lake Baikal seem to be the exception, but it is interesting to note that they live on the deep dark beds of the lake. They lack free swimming larvae and do not swim well as adults, preferring to crawl amongst the grains of sand.

Bathynellaceans females lay one egg at a time. The embryonic development lasts for 9 months (Antrobathynella stammeri) and the newly emerging form is similar to the adult, except that it has fewer legs ( 1 to 4 ) than the adult. The young forms successively acquire legs, up to 8 , in the following moults. The development leads to adults which look like larvae lok, and this has been related with their colonization of the interstitial environment (Coineau, 2000).

They are distributed widely in all the subterranean waters of the world, except at the Poles. At present we know of 2 families, 60 genera and almost 200 species.

There is no known fossil species, but the geographic distribution suggest an origin not later than the upper Paleozoic (Schram, 1977).

The morphology of the adult bathynelids can be summarized by the following characters:

- absence of cephalic caparace;

- presence of 8 thoracic and 5 abdominal free segments;

- eyes and statocysts absent;

- thoracopods 1 to 7 biramous;

- thoracopod 8 male transformed in copulatory organ and female reduced;

- petasma absent; *

- furca always present, and

- uropod with pleotelson not forming tail-fan.

\section{Material and methods}

Bathynellids are rare creatures, and very difficult to colect. The sample used for this study was composed of 11 specimens of Iberobathynella (Espanobathynella) magna Camacho \& Serban, 1998, found in a pool in the Cave CO.246 (Sierra de la Collada, Cantabria, Spain) collected at $-30 \mathrm{~m}$ by C. Puch \& F. Molinero (13/04/2001). Two female specimens were used for the molecular analysis and up to eleven for the morphological identification. All the specimens were frozen at $-20^{\circ} \mathrm{C}$ after sorting from the unfixed sample.

Extraction was carried out with Chelex following Walsh et al. (1991). Specimens were crushed with a pipette tip against the wall of a $1.5 \mathrm{ml}$ microcentrifuge tube. Each tube contained $100 \mu \mathrm{l}$ Chelex 100 (Bio-Rad; 5\% in distilled water) with $2 \mu \mathrm{I}$ proteinase $\mathrm{K}(20 \mathrm{mg} / \mathrm{ml}$; Promega). The specimens were incubated overnight at $56^{\circ} \mathrm{C}$, followed by 10 minutes at $100^{\circ} \mathrm{C}$ and centrifuged at $16,000 \mathrm{~g}$ for 10 minutes.

A fragment of mitochondrial (mt) 16S rDNA was amplified using primers 16Sar (5'-CGCCTGTTTATCAAAAACAT-3') and 16Sbr (5'-CCGGTCTGAACTCAGATCACTG -3') (Palumbi et al., 1991) at $0.4 \mu \mathrm{M}$. Five $\mu \mathrm{l}$ of the Chelex-extracted DNA solution was used as a template. Other components of the $25 \mu \mathrm{l}$ PCR reaction were $75 \mathrm{mM}$ Tris $\mathrm{HCl}$ (pH 9.0), $2 \mathrm{mM} \mathrm{MgCl}, 50 \mathrm{mM} \mathrm{KCl}, 20 \mathrm{mM}$ $\left(\mathrm{NH}_{4}\right)_{2} \mathrm{SO}_{4}, 10 \mathrm{mM} \mathrm{dNTPs}, 0.02 \% \mathrm{BSA}$, and 0.625 units Taq DNA polymerase (Biotools).

PCR was carried out for an initial 10 min denaturation at $95^{\circ} \mathrm{C}$ initial incubation, followed by 40 cycles at $95^{\circ} \mathrm{C}$ for $30 \mathrm{~s}, 51^{\circ} \mathrm{C}$ for $45 \mathrm{~s}$ and $72^{\circ} \mathrm{C}$ for $45 \mathrm{~s}$, and a final extension of $10 \mathrm{~min}$ at $72^{\circ} \mathrm{C}$. The PCR end products were purified and concentrated with Kit Bioclean columns (Biotools) and stored at $4^{\circ} \mathrm{C}$ until sequencing. Each strand was sequenced using "Big Dye Terminator" (Applied Biosystems, Inc; ABI) sequencing reactions for each primer. Sequencing end products were analysed on an $\mathrm{ABI}$ Capillary 3700 Genetic Analyzer.

The DNA sequences were truncated at the primer ends. The CLUSTAL W program (Thompson et al. 1994) was employed to align the $\mathrm{mt} 16 \mathrm{~S} \mathrm{rDNA}$ sequences. Find adjustements were made by eye.

Additional mt 16S rDNA sequences for 23 crustacean species were downloaded from GenBank 
Table 1. Crustacean species used in the phylogenetic analysis and GenBank accession numbers for mt $16 \mathrm{~S}$ rDNA. Classification according to Schram 1986.

Class Remipedia:

Order Nectiopoda:

\section{Spéleonectes gironensis}

(AF370874)

Class Phyllopoda:

Subclass Cephalocarida:

Order Brachypoda:

Subclass Branchiopoda

\section{Hutchinsoniella macracantha} (AF370875)

Order Anomostraca: Branchinecta paludosa

(AF209055)

Class Malacostraca:

Subclass Hoplocarida:

Order Stomatopoda: Gonodactylus chiragra (AF107614)

Squilla empusa (AF107617)

Subclass Eumalacostraca

Superorder Syncarida

Order Anaspidacea: Anaspides tasmaniae (AF133691)

Anaspides spinulae (AF133679)

Allanaspides helonomus

(AF133680)

Allanaspides hickmani

(AF133681)

Paranaspides lacustris

(AF133682)

Order Bathynellacea: Iberobathynella magna

(AF503569, AF503570)

Superorder Peracarída

Order Isopoda: Asellus aquaticus (AJ388077)

Typhlocirolana moraguesi

(AF356849)

Order Cumacea: Cumopsis fagei (AJ388111)

Order Tanaidacea: Apseudes latreillei (AJ388110)

Superorder Eucarida

Order Decapoda

Infraorder Palinura:

Infraorder Caridea

Jasus caveorum (AF192869)

Scyllarides nodifer (U96088)

Macrobrachium atactum (AF374468)

Palaemon serenus (AF439519)

Synalpheus of. bousfieldi " $\mathrm{A}$ "

(AF230260)

Paratya australiensis

(AF439523)

Infraorder Astacida

Astacus astacus (AF235983)

Infraorder Brachyura

Cancer irroratus (AJ130812)

Infraorder Anomura

Aegla affinis (AY50036)
(Table 1). Phyllopoda were used as out-groups for class Malacostraca. The in-group, the class Malacostraca, is represented by the subclases, superorders and orders, following the Lange \& Schram (1999) classification (Table 1). In some cases, more than one species per family or order was included in the analysis. Nucleotide saturation was evaluated by plotting transition and transversion changes against uncorrected (" $p$ ") divergence values. Preliminary treatments based on neighbor-joining (NJ), maximum parsimony (MP), and maximum likelihood principles were carried out using the PAUP* 4.10 package (Swofford, 2002). The best model of evolution that fitted our data was obtained using the program Model test 3.06 (Posada \& Crandall, 1998). Thus, the GTR (General Time Reversible) model (Lavane et al. 1984; Rodríguez et al. 1990) was used. Confidence limits for the analyses were estimated by bootstrapping (5000 repetitions) (Felsenstein, 1985). To determine whether a particular tree topology corresponded to a significantly better or worse interpretation of the data than an alternative tree, we used the Shimodaira-Hasegawa test (Shimodaira \& Hasegawa, 1999), as implemented in PAUP.

\section{Results}

The alignment of the sequences obtained in GenBank together with the new bathynellacean sequences (GenBank accession numbers: AF503569 and AF503570) provided a matrix of 546 characters, including gaps. Two main variable areas were found between the nucleotides 237-294 and 340-377. The transition/transversion ratio was 0.8 , showing in the transversions a saturation tendency for the biggest divergence values (data not shown).

The NJ tree (Fig. 1) showed Speleonectes as the most basal species, considering Branchinecta and Hutchinsoniella as an out-group. The next group to appear was the subclass Hoplocarida (class Malacostraca) with Gonodactylus and Squilla on the one hand and the rest of the in-group, subclass Eumalacostraca (Class Malacostraca) on the other. The analysed specimens of Iberobathynella appeared just in a basal position of this in-group. The rest of the species are grouped following their Superorder: Eucarida and Syncarida as sister groups, and Pera- 

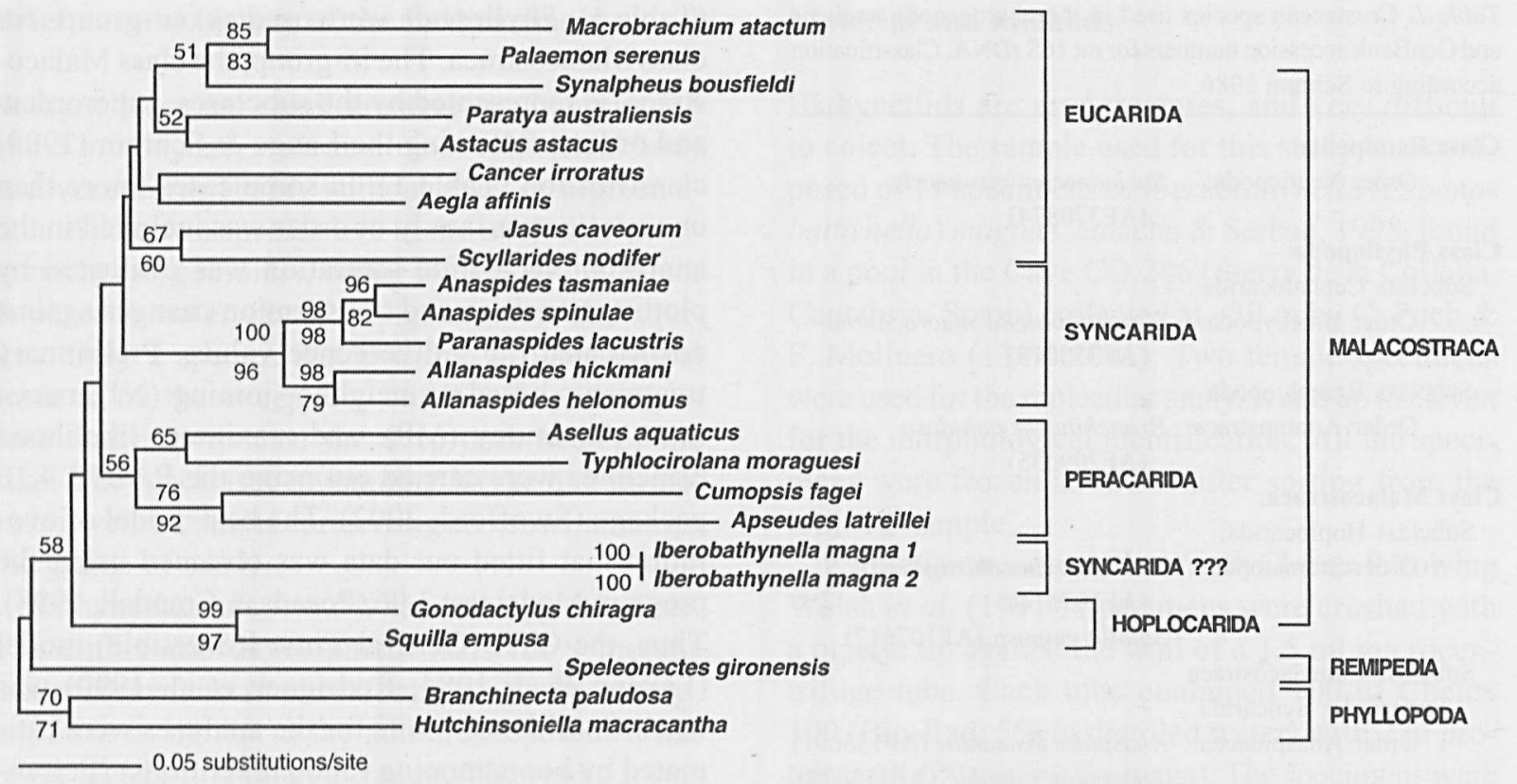

Fig.I. NJ tree based on partial mt $16 \mathrm{~S}$ rDNA. Numbers above branches represent the bootstrap values obtained for 5000 replications corresponding to maximun parsimony and numbers below branches indicate those corresponding to neighbor-joining.

carida species completing the cluster. The bootstrap values mainly supported terminal branches (Fig. 1) where the different taxa of a determinate Superorder are related.

\section{Discussion}

\section{On the phylogenetic relationships of Bathynellacea}

The different views on phylogenetic relationships among crustacean specialists are clearly set out by Serban (1972), where he says that the caparace, which is lacking in the Syncarida, is very well developed in the Eucarida, and is present in intermediate stages of development in the Hoplocarida and Peracarida. Consequently, Serban defined Bathynellacea as: "... un malacostracé à structure paradoxale, une forme archaïque évadée de la classique évolution caridoïde et stylisée de manière singulière." (pp. 114) ${ }^{1}$. The Bathynellacea would be one

I "...a malacostraca with a paradoxical structure, an archaic form beyond the classic caridoid evolution and stylised in a singular way" member of the only lineage that has escaped the most important evolutionary trend in Crustacea: the cephalization of the first thoracic segments. Serban justified the necessity of creating a superorder for the Bathynellacea because of this special and singular "bathynelloid" structural "Bauplän". As a consequence, Serban dismissed the idea of considering the Bathynellacea as a degenerate member of the Syncarida or a structurally simplified syncarid. The corresponding question of whether or not the Bathynellacea are primitive Malacostraca or simplified descendants of this group was an unsolved question in 1972.

Later, Schminke (1981) proposed the so-called zoea theory, which made the origin of the Bathynellacea once again a matter of discussion. Schram (1981) approached the problem from the point of view that the "caridoid" structural basis is the primitive pattern for all Malacostraca and on this basis suggested some relationships, later modified by Hessler (1983). They considered that the differences between Bathynellacea and Anaspidacea could be due to the fact that the former is adapted to interstitial life while the Anaspidacea is epigean. However, this view has been put into doubt since the 
discovery of new syncarids adapted to interstitial life, the family Stygocaridae in the Order Anaspidacea. However, Schram \& Hof (1998) in fact, under some conditions, found Bathynellacea sorting separately from Anaspidacea. It might appear that, the peculiar body plan of the Bathynellacea, very different from the typical Syncarida, cannot be explained easily as an ecological specialization. The Stygocaridae is a clear example of truly primitive syncaridans which, after conquering the subterranean environment, have maintained their peculiar morphology.

As pointed out by Serban (1972), Bathynellacea has a "bathynelloïde" structure (p.114) that is, a mixture of archaic simple carioid Malacostraca characters and a set of specific characters that differentiate them from Malacostraca and Syncarida. In this sense, it is interesting to quote Brooks (1962) (pp.240): "The Bathynellacea with their eight free thoracic somites and furcal lobes definitely have ancient heritage. They are probably descendants of the archaic ancestors of all the Syncarida". We could add that they share with true Syncarida the following characters:

- absence of caparace (all other malacostraceans have one, although sometimes reduced);

- presence of 6 abdominal segments (number reduced in other malacostraceans);

- first thoracic segment always free (in all other malacostraceans it is welded to the cephalic tagma), and

- thoracopods always with epipodites (none or reduced in the other malacostraceans).

However, bathynelids are different from syncarids

in the following:

- the protopod of the thoracopods retain its archaic shape;

- the endopod always has less than 5 segments ( 5 is the typical number in the carioid facies) and the exopod ( 1 to 4 segments) it is never reduced to a flagelum (which is typical in syncarids);

- the vast majority of bathynelid species lack pleopods and those that do have them, have 1 or 2 at most and always reduced (sometimes to a simple seta);

- bathynelids lack statocysts on the antenna I; -

- the males lack a petasma and the thoracopod 8

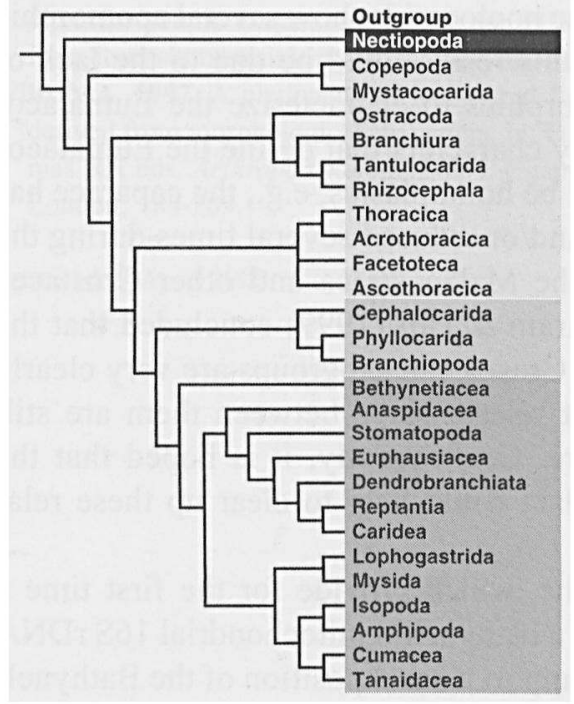

Fig. 2. Crustacean phylogeny inferred by morphology. Slightly modified from Lange \& Schram, 1999.

is transformed into a proper ejaculatory organ, this transformation being unique within the crustacean groups.

Additionally, the development of Bathynellacea is completely different from the syncarids as Serban says (1972) (p.122): “...par ses nombreuses particularités, l'ontogénie de Bathynella s'inscrit parmi les principales caractéristiques qui éloignent les Bathynellacea du super-ordre des Syncarida". The new form that comes out of the egg has fewer thoracopods ( 1 to 4 ) than the adult form, but in syncarids the young animal is identical with the adult (see too Schmincke, 1981).

The most recent works on the phylogeny of Crustacea based on morphological characters (Lange \& Schram, 1999; Schram \& Hof, 1998) suggest that Bathynellacea are an ancestor of the Malacostraca, including the Anaspidacea. However in their classification Bathynellacea is an order of Syncarida within the subclass Eumalacostraca. When fossil forms are included in the analysis, the Syncarida (Bathynellacea, Anaspidacea and Palaeocaridacea) remains a paraphyletic group and ancestor of the Malacostraca (Schram \& Hof, 1998; Wills, 1997). The Hoplocarida appears within the Malacostraca, related sometimes to the Eucarida (Wills, 1997), and at others to the Peracarida or the Syncarida (Schram \& Hof, 1998) (Fig. 2). Taking into ac- 
count that the hoplocarids show several apomorphic characters, this result could be due to the lack of good apomorphies to characterize the Eumalacostraca. Many characters that define the Eumalacostraca could be homoplasies, e.g., the caparace has developed and/or reduced several times during the history of the Malacostraca and other Crustacea groups. Schram \& Hof (1999) concluded that the majority of Crustacean subgroups are very clearly defined, but relationships between them are still very obscure. Consequently, it is hoped that the molecular data could help to clear up these relationships.

Our results, which provide for the first time a sequence of a bathynellid mitochondrial 16S rDNA fragment, support a basal position of the Bathynellacea and a clear distinction from the Superorder Syncarida. Even if the mitochondrial fragment here analysed did not provide a great support for the deeper branches, a Shimodaira-Hasegawa test indicated highly significant difference between the tree topology here proposed and another where the Bathynellacea specimens were forced to appear as sister species of the Syncarida. Our results renew the old controversies on the systematic position of Bathynellacea within Malacostraca. It may be that Serban's (1972) proposal of a new superorder "Podophallocarida" for the Bathynellacea, outside the Syncarida, is worth reconsidering. However, our results point to keeping Podophallocarida within the Eumalacostraca, and there is no need to build a new group Eonomostraca, as Serban suggested. More molecular data are urgently needed to settle these important questions on crustacean relationships.

\section{Acknowledgements}

We gratefully acknowledge $C$. Puch who helped us in different ways. We thank Mark Creb who helped us with the English translations and two anonymous reviewers who gave valuable suggestions. This work was supported by projects PB96-0894, REN2000-2040 GLO, 07M/0125/2000 and PASCALIS (EVK2CT-2001-00121).

\section{References}

Brooks, HK. 1962. On the fossil Anaspidacea, with a revision of the classification of the Syncarida. Crustaceana 4: 239242.

Calman, WT. 1909. Crustacea. In: A Treatise on Zoology. Lankester ER, ed. London: Adams \& Charles Black VII.

Camacho AI., Serban E. 1998. Tribu des Iberobathynellini nov. Diagnoses des taxa nouveaux (Parabathynellidae, Bathynellacea, Podophallocarida). Trav. Inst. Spéol. "Émile Racovitza» t. XXXIV (1995): 15-75.

Coineau N. 2000. Syncarida. Inx Jubertie, C. \& V. Decu eds. Encyclopaedia Biospeologica. Socíté de Bíospéologie, Moulis (CNRS)- Bucarest (Académie Roumaine) 863-876.

Felsenstein J. 1985. Confidence limits on phylogenies: An approach using the bootstrap. Evolution 39: 783-791.

Hessler RR. 1983. A defense of the caridoid facies; wherein the early evolution of the Eumalacostraca is discussed. Crust. Issues 1: 145-164.

Lange S, Schram FR. 1999. Evolución y Filogenia de los crustáceos. In: Melic A, De Haro JJ, Mendez M, Ribera I, eds. Evolución y Fllogenia de Arthropoda. Zaragoza: Bol. SEA $n^{\circ} 26: 235-254$.

Lavane C, Preparata G, Sacone C, Serio G. 1984. A new method for calculating evolutionary substitution rates. J. Mol. Evol. 20: 86-93.

Palumbi, SR, Martin, AP, Romano S, McMillan WO, Stice L, Grabowski G. 1991. The Simple Fool's Guide to PCR. Special Publ. Dept. Zoology, University of Hawaii, Honolulu.

Posada D, Crandall KA. 1998. Model test: testing the model of DNA substitution. Bioinformatics 14: 817-818.

Rodriguez R, Oliver JL, Marin A, Medina JR. 1990. The general stochastic model of nucleotide substitution. J. Theor. Biol. 142: 485-501.

Serban E. 1970. A propos du genre Bathynella Vejdovsky (Crustacea, Syncarida). In: Livre du centenaire Émile G. Racovitza, ed. Académie, Bucarest, 265-273.

Serban E. 1972. Bathynella (Podophallocarida, Bathynellacea). Trav. Inst. Spéol. "Émile Racovitza » XI: 1-398.

Schminke HK. 1981. Adaptations of Bathynellacea (Crustacea, Syncarida (to life in the interstitial ("Zoea theory"). Int. Rev Gesamten Hydrobiol. 66: 578-637.

Schram FR. 1977. Palaeozoogeography of Late Paleozoic and Triassic Malacostraca. Syst. Zool, 26: 367-379.

Sehram FR. 1981. On the classification of the Eumalacostraca. J. Crustac. Biol. 1: 1-10.

Schram FR, Hof, CHJ. 1998. Fossils and the interrelationships of major Crustacean group. Inx Edgecombe GD, ed. Arthropod Fossils and Phylogeny. Columbìa University Press, New York, 233-302.

Shimodaira H, Hasegawa, M. 1999. Multiple comparisons of log-likelihoods with applications to phylogenetic inference. Mol. Biol. Evol. 16: 1114-1116.

Swofford DL. 2002, PAUP*: Phylogeny Analysis Using Parsimony ("and other methods), version 4.0b9. Sinauer Associates Inc., Sunderland, Massachusetts. 
Thompson JD, Higgins DG, Gibson T. 1994. CLUSTAL W: improving the sensitivity of progressive multiple sequence alignment through sequence weighting, position-specific gap penalties and weight matrix choice. Nucleic Acids Research 22: $4673-4680$.

Vejdovsky FR. 1882, Thierische Organismen der Brunnenwässer von Prag. Prague, 1-70.

Walsh P, Metzger D, Higuchi R. 1991. Chelex 100 as a me- dium for simple extraction of DNA for PCR-based typing from forensic material. Biotechniques 10:506-513.

Wills MA. 1997. A phylogeny of recent and fossil Crustacea derived from morphological characters. In: Fortey RA, Thomas RH eds. Arthropod Relationships. Chapman and Hall, London, 189-209.

Received: 9 April 2002 